\title{
SILAGEM ÁCIDA DE RESÍDUOS DE TRUTA (Oncorhynchus mykiss), COM A UTILIZAÇÃO DE ÁCIDO MURIÁTICO
}

\author{
Acid silage of trout waste (Oncorhynchus mykiss), using muriatic acid
}

\author{
Eduardo Lopes Beerli ${ }^{1}$, Karla Michalsky Carvalho Beerli ${ }^{2}$, Priscila Vieira Rosa Logato ${ }^{3}$
}

\begin{abstract}
RESUMO
O destino dos resíduos da piscicultura sempre foi um problema para os produtores. Além de serem poluentes, são desperdiçados produtos de alto valor nutritivo. Realizou-se este trabalho com o objetivo de viabilizar ao pequeno e médio produtor um processo de reaproveitamento dos resíduos da piscicultura, a partir de uma silagem ácida. A silagem com ácido muriático foi elaborada em 16 silos, sendo 4 tratamentos e 4 repetições com $2.000 \mathrm{~g}$ de resíduo moído/silo e, respectivamente, 150, 200, 300 e $350 \mathrm{ml}$ ácido/tratamento, durante 3 semanas; o pH foi monitorado diariamente. Foram realizadas análises de Contagem Total de Microrganismos e Coliformes Totais após 1 e 3 semanas e análise de coliformes a $45^{\circ} \mathrm{C}$ após 3 semanas. Com essas análises determinaram-se baixa contagem bacteriana e ausência de Coliformes a $45^{\circ} \mathrm{C}$, tornando o produto adequado ao consumo animal.
\end{abstract}

Termos para indexação: Alimentação, alimento alternativo, monogástricos, nutrição, peixes, vísceras.

\begin{abstract}
The destiny of aquaculture wastes was always a problem to the producers. Besides pollute, they are wastes with high nutritive value. The objective of this research was to produce acid silage using aquaculture wastes. The silage using meiotic acid was elaborated in 16 silos, 4 treatments and 4 replications with $2.000 \mathrm{~g}$ of grinded fish/silo and respectively 150, 200, 300 and $350 \mathrm{ml}$ acid/treatment, during 3 weeks. The $\mathrm{pH}$ was diary accompanied. Total Count of Microorganisms and Total Coliforms analysis was realized after 1 and 3 weeks and Coliforms at $45^{\circ} \mathrm{C}$ after 3 weeks. These analysis determinate low bacteria concentration and absence of Coliforms at $45^{\circ} \mathrm{C}$, changing the product adequate to animal feed.
\end{abstract}

Index terms: Alternative feed, fish, feed, guts, monogastrics, nutrition.

(Recebido para publicação em 18 de novembro de 2002 e aprovado em 6 de janeiro de 2003)

\section{INTRODUÇÃO}

O destino dado aos resíduos da piscicultura constitui um problema para os produtores. O aproveitamento desses resíduos, de forma eficiente, nas silagens trará vantagens econômicas, permitirá o aparecimento de novos produtos e eliminará o problema de poluição ambiental.

A silagem pode ser produzida com o peixe inteiro ou com o material residual. A silagem de peixe é atualmente utilizada para ração animal, como fonte de proteína, não devendo ser considerada como um competidor da farinha de peixe, e sim como uma alternativa.

Entre as vantagens da produção da silagem em relação à farinha de peixe, pode-se citar que o produto é de maior digestibilidade, o processo é virtualmente independente de escala, a tecnologia é simples, mesmo para produção em larga escala, o capital gasto é pequeno, os efluentes e odores são reduzidos, não é necessário armazenamen- to do produto refrigerado, o processo é rápido em climas tropicais e o produto pode ser utilizado de imediato.

A silagem líquida de pescado é fonte de proteína de alta qualidade e minerais para a alimentação animal; é versátil e pode ser utilizada como suplemento da ração de vários animais, como peixes, suínos, ovelhas, gado e aves domésticas (HAARD et al., 1985). A silagem de pescado é usada na Escandinávia na alimentação de animais e peixes, dado o seu alto valor nutritivo (MANIKADALEVU et al., 1992; DAS et al., 1993). A preservação se mantém por mais de um ano e o aroma desprendido é ácido (STROM et al., 1979).

A adição de formaldeído, após a liquefação se completar, serve para prevenir a hidrólise contínua e a rancificação. Esse procedimento é recomendado para uso da silagem de pescado em mistura com forragem, na alimentação de ruminantes. Outros aditivos são recomendados, como o sorbato de potássio, para evitar o desenvolvimento de fungos. (HAARD et al., 1985; ESPE et al., 1989).

\footnotetext{
1. Mestrado em Aquacultura - Universidade Federal de Lavras/UFLA - Caixa Postal 37 - 37200-000 - Lavras, MG.

2. Mestrando em Microbiologia de Alimentos - UFLA.

3. Doutorado em Nutrição de Monogástricos Professora do Departamento de Zootecnia - UFLA.
} 
Objetivou-se com este trabalho elaborar a silagem ácida de resíduos de truta utilizando-se ácido muriático, em diferentes proporções, e realizando as análises microbiológicas para determinar a quantidade de ácido que garanta a qualidade do produto final.

\section{MATERIAL E MÉTODOS}

A matéria-prima se constituiu de resíduos de filetagem de truta, sendo esses cabeça, espinha e vísceras, doados por um produtor da região de Lavras-MG. Esses resíduos foram moídos em máquina elétrica de moer carne, de modo que o produto resultante ficou com textura pastosa. $\mathrm{O}$ produto obtido foi misturado de modo a obter uma massa homogênea.

A massa homogênea foi dividida em lotes e colocada em silos experimentais de cano de PVC de 4 polegadas e $40 \mathrm{~cm}$ de altura. Cada um dos 16 silos recebeu $2.000 \mathrm{~g}$ de massa homogênea e foram divididos em quatro tratamentos de quatro repetições. Os tratamentos receberam 150, 200, 300 e $350 \mathrm{ml}$ de ácido muriático ( $\mathrm{HCl}$ comercial) da marca $\mathrm{FOX}$ por silo, o que representa uma concentração de 75, 100, 150 e $175 \mathrm{ml} / \mathrm{kg}$ de resíduo moído, respectivamente, para cada tratamento.

Em cada silo, o produto foi revolvido com um bastão, visando a misturar o ácido à massa. Os silos foram, então, fechados com suas tampas, numerados e deixados em repouso na vertical. Duas vezes por dia, durante uma semana, o produto foi homogeneizado da mesma forma.

Após a preparação das silagens, foi realizado um acompanhamento visando à cor, aroma e textura.

As amostras submetidas às análises microbiológicas foram retiradas em dois tempos distintos. A primeira, uma semana após a inoculação do ácido, e a segunda, três semanas após. Os silos foram revolvidos e um volume igual de material foi retirado de cada tratamento e misturado, visando a obter as amostras compostas representativas de cada tratamento.

$\mathrm{O}$ pH foi determinado em pHmetro digital, que proporciona leitura de duas casas decimais, sempre precedido de revolvimento da massa. Desde a inoculação do ácido, foi realizada diariamente a medição do pH para observar a variação do mesmo durante o processo.
Visando a analisar a qualidade microbiológica da silagem, foram realizadas culturas microbiológicas a partir das amostras de cada tratamento. Foram realizadas duas séries de análises, uma semana e três semanas após a adição do ácido.

Em cada série, foi realizada a Contagem Total de Microrganismos em meio PCA, utilizando diluições de $10^{-2}$ a $10^{-7}$ e duas placas de contagem para cada diluição; a análise de Coliformes Totais em meio Lauryl com as mesmas diluições e três tubos de cultivo para cada diluição, e a análise de Coliformes a $45^{\circ} \mathrm{C}$ no meio EC (caldo E. colli), apenas para os tratamentos que apresentarem resultados positivos na análise de Coliformes Totais.

\section{RESULTADOS E DISCUSSÃO}

Observou-se que o aroma característico do peixe desapareceu em pouco tempo (cerca de 1 ou 2 dias), dando lugar a um cheiro ácido, que também era forte no início e se tornou brando com o decorrer dos dias.

A textura pastosa foi se tornando líquida e, ao término de uma semana, todo o material estava em partículas menores do que as iniciais, tornando o produto praticamente líquido. Após uma semana, o produto está pronto para ser utilizado, mas foi observado que o ácido continua agindo, tornando a silagem ainda mais líquida.

As maiores partículas restantes foram pequenos fragmentos de ossos da coluna vertebral das trutas, com cerca de $0,5 \mathrm{~cm}$ de diâmetro. Todo o material cárneo foi dissolvido.

Uma pequena camada de óleo se formou na parte superior do produto. Nas misturas diárias, essa camada foi sempre revolvida, com o objetivo de colocá-la novamente em contato com o ácido e evitar a ocorrência de rancidez oxidativa no material.

A coloração inicial da massa homogênea passou de marrom com tons avermelhados para marrom-claro ao final do processo.

Observou-se que o processo não necessita ser anaeróbico como nas silagens de outros produtos, pois, nesse, os microorganismos deixam de ter o papel principal nas transformações do material, o que passa a ser realizado pelo ácido. Quando esse método for utilizado, é aconselhável que se deixe um orifício por onde os gases possam escapar. 
TABELA 1 - Valores de pH da silagem em três tempos distintos, imediatamente após a adição do ácido, uma semana após o início do processo e três semanas após o início.

\begin{tabular}{ccccc}
\hline & $\begin{array}{c}\text { Tratamento 1 } \\
(\mathbf{1 5 0} \mathbf{~ m l})\end{array}$ & $\begin{array}{c}\text { Tratamento 2 } \\
\mathbf{( 2 0 0} \mathbf{~ m l})\end{array}$ & $\begin{array}{c}\text { Tratamento 3 } \\
\mathbf{( 3 0 0} \mathbf{~ m l})\end{array}$ & $\begin{array}{c}\text { Tratamento 4 } \\
\mathbf{( 3 5 0} \mathbf{~ m l})\end{array}$ \\
\hline Imediatamente & 3.41 & 2.78 & 2.01 & 1.31 \\
Uma semana & 3.60 & 3.10 & 1.51 & 1.39 \\
Três semanas & 3.53 & 3.06 & 1.53 & 1.43 \\
\hline
\end{tabular}

Utilizando-se o ácido muriático em quatro concentrações, obtiveram-se os seguintes valores médios de $\mathrm{pH}$, imediatamente após a adição do ácido, uma semana após o início do processo e três semanas após o início.

Os resíduos de truta, assim como de qualquer outro pescado, contêm grande quantidade de microrganismos e, para ser eficiente, o processo de silagem ácida deve reduzir essa quantidade, tornando o resíduo utilizável para a alimentação animal.

Segundo Dias (1996), a silagem produzida apenas com ácidos inorgânicos tem que ter um $\mathrm{pH}$ de 2.0, para evitar a ação bacteriana. Portanto, os valores de $\mathrm{pH}$ utilizados neste trabalho cobrem valores tanto acima como abaixo do $\mathrm{pH} 2.0$.

Com a primeira medição do $\mathrm{pH}$, imediatamente após a adição do ácido, foram obtidos valores que não se mantiveram constantes em relação às outras medições. Isso provavelmente se deve ao fato de o ácido não ter interagido com os resíduos das trutas. O contrário pode ser observado nas medições seguintes, pois as outras duas medições permaneceram com valores bem próximos de $\mathrm{pH}$, o que significa que o processo alcança um valor de $\mathrm{pH}$ mais ou menos estável no decorrer do processo.

$\mathrm{Na}$ primeira série de análises microbiológicas, uma semana após a adição do ácido muriático, o resultado da Contagem Total de Microrganismos encontra-se na Tabela 2.

E o resultado da análise de Coliformes Totais encontra-se na Tabela 3.

De acordo com esses resultados, os tratamentos 3 e 4 estariam aparentemente estéreis e todos os tratamentos estariam sem coliformes, mas deve-se lembrar de que a menor diluição utilizada para essas análises foi de $10^{-2}$ e de que os microorganismos certamente estariam presentes na diluição de $10^{-1}$ ou na análise utilizando amostra sem diluição (Direta).
TABELA 2 - Resultado da Contagem Total de Microrganismos uma semana após a adição do ácido muriático aos resíduos.

\begin{tabular}{cc}
\hline & Contagem Total \\
\hline Tratamento 1 & $2.03 \times 10^{6} \mathrm{UFC} / \mathrm{ml}$ \\
Tratamento 2 & $1.17 \times 10^{6} \mathrm{UFC} / \mathrm{ml}$ \\
Tratamento 3 & ausente \\
Tratamento 4 & ausente \\
\hline
\end{tabular}

TABELA 3 - Resultado da análise de Coliformes Totais uma semana após a adição do ácido muriático aos resíduos.

\begin{tabular}{cc}
\hline & Coliformes Totais \\
\hline Tratamento 1 & ausente \\
Tratamento 2 & ausente \\
Tratamento 3 & ausente \\
Tratamento 4 & ausente \\
\hline
\end{tabular}

Três semanas após a incorporação do ácido, novas amostras foram retiradas a fim de se realizarem as mesmas análises microbiológicas e os resultados estão apresentados nas tabelas a seguir.

TABELA 4 - Resultado da Contagem Total de Microorganismos três semanas após a adição do ácido muriático aos resíduos.

\begin{tabular}{cc}
\hline & Contagem Total \\
\hline Tratamento 1 & $6.2 \times 10^{5} \mathrm{UFC} / \mathrm{ml}$ \\
Tratamento 2 & $1.6 \times 10^{5} \mathrm{UFC} / \mathrm{ml}$ \\
Tratamento 3 & $5.3 \times 10^{2} \mathrm{UFC} / \mathrm{ml}$ \\
Tratamento 4 & ausente \\
\hline
\end{tabular}


TABELA 5 - Resultado da análise de Coliformes Totais três semanas após a adição do ácido muriático aos resíduos.

\begin{tabular}{cc}
\hline & Coliformes Totais \\
\hline Tratamento 1 & $0.4 \mathrm{NMP} * / \mathrm{ml}$ \\
Tratamento 2 & $1.5 \mathrm{NMP} / \mathrm{ml}$ \\
Tratamento 3 & ausente \\
Tratamento 4 & ausente \\
\hline
\end{tabular}

*NMP: Número Mais Provável

Para os tratamentos 1 e 2 , foram realizadas análises de Coliformes a $45^{\circ} \mathrm{C}$ e nenhuma apresentou resultado positivo.

Como se pode observar, pela Contagem Total verifica-se exatamente que quanto mais ácido, menor o número de microorganismos presentes. E que, com a análise de Coliformes Totais, pode-se perceber que, nas proporções de 75, 100, 150 e $175 \mathrm{ml} /$ $\mathrm{kg}$ de resíduo moído, a silagem ácida que utiliza o ácido muriático não apresenta problemas de alta contaminação, o que justifica sua utilização, pelo fato de que a análise de Coliformes a $45^{\circ} \mathrm{C}$ não apresentou resultado positivo, a análise de Coliformes Totais apresentou valores muito baixos, e a Contagem Total, valores baixos.

Como a Contagem Total de Microorganismos também serve de parâmetro para analisar a qualidade dos alimentos, pode-se perceber que, para menores quantidades de ácidos adicionadas, ou seja, abaixo de $75 \mathrm{ml} / \mathrm{kg}$ de resíduo moído, a contagem apresentará maiores quantidades de microorganismos, o que comprometerá a qualidade da silagem ácida.

Neste trabalho, utilizando o ácido muriático no lugar do fórmico, pode-se constatar a eficiência daquele para a confecção da silagem ácida de resíduos de truta.

Algumas vantagens puderam também ser observadas, tais como: o custo do ácido muriático é menor que do fórmico, passando de $\mathrm{R} \$ 54,00$ a $\mathrm{R} \$ 1,60$ por litro do ácido, diminuindo-se os custos de produção. Constatou-se que o ácido fórmico é cancerígeno e não deve ser utilizado no processamento de produtos destinados à alimentação animal, que o ácido muriático apresenta odor mais fraco e que é de mais fácil obtenção, pois pode ser facilmente encontrado em lojas de materiais de construção.
A manufatura da silagem ácida é muito simples, com necessidade de pouca mão-de-obra, podendo-se se tornar a saída mais limpa para resolver o problema dos resíduos de peixes do Brasil.

\section{CONCLUSÕES}

De acordo com as condições deste experimento, conclui-se que

a) A silagem está pronta para ser utilizada uma semana após a adição do ácido, devido a sua textura, odor, cor e $\mathrm{pH}$;

b) O ácido muriático reduziu a contagem de microrganismos a níveis aceitáveis para a alimentação animal, em todos os tratamentos testados.

\section{REFERÊNCIAS BIBLIOGRÁFICAS}

DAS, H. K.; HATTULA, M. T.; MYLLYMÄKI, O. M.; MALKKI, Y. Effects of formulation and processing variables on dry fish feeds pellets containing fish waste. Journal of Food and Science, Champaign, v. 61, p. 181-187, 1993.

ESPE, M.; RAA, J.; NJAA, L. R. Nutricional value of stored fish silage as a protein souce for young rats. Journal of Science Food and Agriculture, London, v. 49, p. 259-270, 1989.

HAARD， N. F.; KARIEL， N.; HERZBERG， G.; FELTHAM, L. A. W.; WINTER, K. Stabilization of protein and oil in fish silage for use as a ruminante feed suplement. Journal of Science Food and Agriculture, London, v. 36, p. 229-241, 1985.

MANIKADAVELU, D.; NEETHISELVAN, J.; JAGATHEESAN, J.; SUNDARSANAM, K. Use of fermented ensilage based diet in enhancing the growth of common carp (Cyprinus carpio var. communis). Fishery Technology, Cochin, v. 29, p. 111-113, 1992.

DIAS, J. L. S. Silagem ácida de peixe: manuseio de salmonídeos. [S.l.: s.n.], 1996. 40 p.

STROM, T.; GILBERT, A.; STORMO, B.; RAA, J. Fish silage: why not use propionic and formic acid? Advances Fish Science Technology, Surrey, p. 352$355,1979$. 